\title{
REHABILITASI SOSIAL EKONOMI BERBASIS SYARIAH BAGI KORBAN NAPZA DI YAYASAN GRAPIKS KABUPATEN BANDUNG
}

\section{SHARIA-BASED SOCIAL ECONOMIC REHABILITATION FOR DRUG VICTIMS AT GRAPIKS FOUNDATION BANDUNG REGENCY}

\author{
P Srisusilawati 1a, P A A Putra1 , A T Utami1 , A Siregar1, Y G Rois 1, Tahany¹ , F S Rosyidah 1 \\ ${ }^{1}$ Fakultas Syariah Universitas Islam Bandung Jalan Ranggagading No. 08 Kota Bandung Provinsi \\ Jawa Barat Indonesia \\ aKorespondensi:Popon Srisusilawati; E-mail: po2nss@gmail.com \\ (Diterima: 16-09-2019; Ditelaah: 17-09-2019; Disetujui: 31-03-2020)
}

\begin{abstract}
The purpose of the implementation of sharia-based social-economic rehabilitation PKM activities for drug victims in the Graphics foundation in the village of Cimekar, Cileunyi, Bandung, Bandung, is to provide solutions to the problems that have been faced, namely the tendency of former drug users to re-use very large. Rejection from families and the environment against drug victims, this rejection is related to their survival in economic terms, so they need skills development and how to socialize again with the surrounding community. Therefore the application of the sharia system in socio-economic rehabilitation is very important for drug victims who have an impact on the level of the economy and the welfare of former drug victims. It is clear that the psychic and economic condition of the former victim of this drug needs to be developed with sharia-based social-economic rehabilitation. The specific target to be achieved is the change in behavior of former victims of drugs. They are increasing the quality of SDI victims of drugs. The method used is the first approach to assisting behavioral change carried out continuously by involving family or spouse. Second, business/skill assistance is by exploring the potential of a former drug victim. The activities carried out are assisting with behavioral change by instilling Islamic principles so that they can go back to the community, explore the potential of drug victims by providing entrepreneurial training in accordance with Islamic law. Assistance is carried out until the end of the PKM program and after the PKM program ends. As a result of the PKM there was an increase in understanding of diversity regarding drugs and increasing the skills of drug victims.

Keywords: Sharia-based socio-economic rehabilitation, Drug Victims, Graphics Foundation.
\end{abstract}

\begin{abstract}
ABSTRAK
Tujuan dari pelaksanaan kegiatan PKM rehabilitasi sosial ekonomi berbasis syariah bagi korban napza di yayasan Grapiks desa cimekar kecamatan Cileunyi kabupaten Bandung yaitu untuk memberikan solusi atas permasalahan yang selama ini dihadapi yaitu kecenderungan mantan korban Napza kembali menggunakan sangat besar. Penolakan dari keluarga dan lingkungan terhadap para korban Napza, penolakan ini yang berhubungan dengan keberlangsungan hidup mereka dalam segi perekonomian, sehingga mereka membutuhkan pengembangan keterampilan dan bagaimana bersosialisasi lagi dengan masyarakat sekitar. Oleh karena itu penerapan sistem syariah dalam rehabilitasi sosial ekonomi sangat penting bagi korban napza yang berdampak pada tingkat perekonomian dan kesejahteraan mantan korban napza. Hal ini jelas psikis dan perekonomian mantan korban Napza ini perlu dikembangkan dengan rehabiitasi sosial ekonomi berbasis syariah. Target khusus yang ingin dicapai yaitu perubahan perilaku mantan korban napza. Meningkatnya kualitas dari SDI korban Napza. Metode pendekatan yang ditempuh yaitu pertama pendampingan perubahan perilaku dilakukan secara berkesinambungan dengan melibatkan keluarga atau pasangan. Kedua pendampingan usaha/keterampilan yaitu dengan penggalian potensi yang dimiliki seorang
\end{abstract}


mantan korban napza. Kegiatan yang dilakukan yaitu Pendampingan perubahan perilaku dengan ditanamkannya dasar-dasar keislaman agar mereka bisa terjun kembali ke masyarakat, menggali potensi korban napza dengan memberikan pelatihan kewirausahaan yang sesuai dengan syariat Islam. Pendampingan dilakukan hingga akhir masa pelaksanaan program PKM dan setelah program PKM ini berakhir. Hasil dari PKM ini adanya peningkatan pemahaman keagaman mengenai Napza dan meningkatnya keterampilan korban Napza.

Kata kunci : Rehabilitasi sosial ekonomi berbasis syariah, Korban Napza, Yayasan Grapiks.

Srisusilawati, P., Putra, P. A. A., Utami, A. T., Siregar, A., Rois., G., \& Rosyidah, F. S. (2020). Rehabilitas

Sosial Ekonomi Berbasis Syariah Bagi Napza di Yayasan Grapiks Kabupaten Bandung. Jurnal

Qardhul Hasan : Media Pengabdian kepada Masyarakat, 6(1), 79-87.

\section{PENDAHULUAN}

Masalah penanggulangan NAPZA seringkali hanya sebatas bagaimana pencegahan, pemberantasan pengedar, penangkapan para penyalahguna NAPZA dan proses terapi. Seharusnya penganggulangan NAPZA tidak hanya sebatas itu, tetapi perlu juga memikirkan dampak yang ditimbulkan pada penyalahgunanya. Peredaran dan perdagangan yang terjadi di Indonesia secara ilegal, merupakan suatu kejahatan dan tidak sedikit menimbulkan masalah bagi penyalahgunanya. Baik secara sadar maupun tidak sadar, mereka adalah korban kejahatan. Secara justifikasi di lingkungan keluarga dan masyarakat luas, penyalahguna NAPZA adalah seorang penyalahguna yang membuat tidak nyaman orang-orang di sekelilingnya.

Perkembangan penyalahgunaan dan peredaran gelap narkoba yang melanda dunia juga berimbas ke tanah air, narkoba dan obat-obatan psikotropika sudah merambat ke seluruh wilayah tanah air dan menyasar ke berbagai lapisan masyarakat Indonesia tanpa terkecuali. BNN mencatat, Prevalensi penyalahgunaan narkoba di kota bandung pada tahun 2015 mencapai 1,40\% atau sebanyak 25.427 orang. Sementara itu, ditahun 2017 Polrestabes Bandung mendata ada 277 kasus penyalahgunaan narkoba dengan 373 orang tersangka. Sedangkan penyalahgunaan narkotika di kabupaten Bandung itu 50\% nya usia pekerja dan antara laki-laki dan perempuan hampir sama. Hal ini menjadi perhatian khusus BNN dalam pengurangan korban napza di kabupaten Bandung (Jabar.Tribunnews.com Sabtu, 28 Juli 2018).

Masalah penyalahgunaan NAPZA, terutama penanganan terhadap penyalahgunaannya sendiri, merupakan tantangan bagi semua pihak, karena bukan hal mudah menangani korban penyalahguna NAPZA dimana mereka memiliki penyakit kronis dan bersifat kambuhan, artinya pengguna NAPZA memiliki kecenderungan untuk menggunakan kembali atau relapsing. Selain itu kebiasaan yang seringkali membuat ketidaknyamanan bagi orangorang di lingkungannya saat mereka masih aktif menggunakan NAPZA.

Disadari ataupun tidak situasi lingkungan seperti ini menjadikan terjadinya penolakan keluarga, masyarakat, dan lingkungan tempat dia tinggal. Situasi lainnya seperti kemungkinan-kemungkinan dia bertemu dengan teman pakainya juga masalah lainnya yang berpengaruh pada ketidakmampuannya dalam mempertahankan kepulihannya. Situasi tersebut adalah situasi yang menyulitkan bagi para pengguna yang sedang menjalani proses pemulihan bagi para pengguna yang sedang menjalani proses pemulihan dan mempertahankan kepulihannya. Oleh karena itu penting dilakukannya After Care yaitu salah satu bagian dari metode untuk mengembalikan mereka pada kebiasaan sebelum menjadi pengguna NAPZA yaitu mengembalikan fungsi-fungsi spiritual mereka yang lama telah hilang sejak adiksi menjangkitinya, sehingga situasi-situasi diatas dapat diatasi dan mendapatkan penerimaan kembali dari keluarga maupun masyarakat. Penerimaan ini akan menjadi kekuatan bagi mereka untuk memotivasi 
diri dengan menganggapnya sebagai hadiahhadiah atas pemulihan yang sedang berlangsung, sehingga kekuatannya untuk tetap asertif dalam menolak ajakan temanteman pakainya dapat menjadi kekuatan bagi penyelesaian yang positif saat sugesty dan kerinduan untuk menggunakan NAPZA muncul.

Disisi lain sebagaimana manusia pengguna NAPZA juga harus mampu mempertahankan hidupnya, kebutuhan-kebutuhan primernya sebagai manusia tetap harus dipenuhi. Keberlangsungan hidup mereka juga harus dipandang sebagai hal yang penting dan memiliki dampak positif terhadap upaya mempertahankan kepulihannya. Pemberdayaan pengguna NAPZA pada sisi ekonomi menjadi penting untuk kelangsungan hidupnya, begitu juga bagi keluarganya. Korban napza yaitu mitra dalam PKM ini yang ada di Yayasan Grapiks adalah salah satu lembaga sosial/nirlaba yang ada di wilayah Kabupaten Bandung khususnya di Daerah Kecamatan Cileunyi.

Gambar 1. Mitra dalam PKM ini yang ada di Yayasan Grapiks.



Keterbatasan pengetahuan dan keterampilan kelompok mantan korban napza pada umumnya disebabkan karena kurangnya perhatian akan masalahan perekonomian hanya terfokus pada perubahan perilaku penggunaan napza nya saja. Sehingga masalah keterampilan usaha terabaikan. Hal ini yang membuat mitra semakin terpuruk. Padahal mereka pun sama sebagai manusia berhak untuk mendapatkan penghidupan yang layak.

Rehabilitasi sosial ekonomi berbasis syariah ini merupakan model rehabilitasi yang memberikan dampingan kepada korban napza dengan menerapkan rehabilitasi dari sisi psikis dan menggali keterampilan korban napza dengan sistem syariah, hal ini sesuai dengan renstra LPPM Unisba.

Kecenderungan mantap korban napza sangat besar untuk kembali ini dikarenakan kurangnya dukungan dari keluarga atau pasangan, pengucilan dari masyarakat sekitar dan keluarga membuat mereka akan kembali ke komunitasnya. Hal tersebut yang harus dihindari sehingga mereka membutuhkan perhatian khusus dari keluarga atau pasangan. Dibutuhkan pendampingan khusus akan hal itu. Pemberian keterampilan usaha merupakan salah satu pendampingan dalam mengembangkan keterampilan mitra sehingga mereka akan terfokus akan usaha yang mereka miliki, namun sekarang ini usaha mitra yang ada hanya sekedar tersedia tanpa belom adanya pengelolaan yang sesuai. Keahlian mereka dalam usaha tersebut belom begitu menguasai. Melanjutkan hidup dengan aktifitas yang disenanginya sehingga diharapkan mitra dapat tidak merasa tertekan dengan aktifitas yang dijalankannya dan berdaya secara ekonomi syariah sehingga dapat melanjutkan hidupnya dengan pendapatan yang memadai dan mampu mengontrol perasaan-perasan yang akan membawanya kembai relaps.

Uraian di atas dapat disimpulkan bahwa bila diadakan pendampingan Rehabilitasi sosial ekonomi berbasis syariah baik dari segi psikologi dan ekonominya ini akan meningkatkan kepercayan diri dan meningkatkan perekonomian mantan korban NAPZA yang sesuai dengan syariat Islam.

Hasil pengamatan dan wawancara dengan pengurus yayasan Grapiks menunjukan bahwa kecenderungan mantan korban Napza ini untuk kembali menggunakan kembali sangat besar. Penolakan dari keluarga dan lingkungan terhadap para korban Napza, penolakan ini yang berhubungan dengan keberlangsungan hidup mereka dalam segi perekonomian, sehingga mereka membutuhkan pengembangan keterampilan yang masih rendah. Oleh karena itu kurangnya dukungan dan usaha mereka yang belum 
berkembang secara baik yang berdampak pada tingkat perekonomian dan kesejahteraan mantan korban napza.

Untuk mendapatkan gambaran permasalahan yang dihadapi mantan korban napza mitra secara spesifik, telah dilakukan diskusi/pertemuan dengan ketua yayasan grapiks, pengurus dan mantan korban napza. Hasil diskusi tersebut berhasil merumuskan beberapa permasalahan spesifik yang dihadapai mitra kelompok mantan korban napza.: Beberapa permasalahan tersebut adalah:

\section{Perubahan perilaku}

Kebiasan-kebiasan lamanya yang telah bertahun-tahun melekat pada diri seorang korban napza aktif telah menjadi karakter yang melekat pada dirinya. Adiksi telah menyebabkan perubahan pada fisik maupun psikis seorang korban napza, sehingga nilainilai spiritual yang tertanam dari pendidikan keluarga dan lingkungan yang positif telah hilang. Situasi ini tentu bukan hal yang sederhana, karakter yang cenderung negatif ini dipengaruhi oleh situasi kecenderungan yang dialaminya. Perubahan yang terlihat antara lain sering berbohong, mudah marah/tersinggung, berkata kasar, perawatan diri kurang, serta melakukan tindak kekerasan hingga kriminal. Hal terseut tentunya menimbulkan penderitaan tidak saja bagi dirinya tapi keluarga dan lingkungan sekitarnya. Penderitan-penderitaan yang disebabkan oleh hal tersebut menjadi bagian persoalan bagi upaya pemulihan korban napza. Kesakithatian, ketidakpercayaan orang lain terhadap korban napza menjadikan mereka sulit mempertahankan kepulihan.

\section{Usaha/ keterampilan}

Penggalian potensi yang dimiliki seorang korban napza adalah bagian proses membangun perubahan dan pola-pola perilaku baru pada seorang korban napza yang selama hidupnya selalu ingin dan mengambil pilihan-pilihan yang instans. Mengembalikan kepercayaan mereka akan kemampuan yang mereka miliki itu yang sangat sulit. Kebiasan mereka dengan pilihan yang instans itu membuat mereka menyepelakan akan usaha yang mereka lakukan. Usaha yang mereka lakukan di laksanakan dengan tidak serius. Keahlian yang belum begitu nampak dari mitra hal tersebut yang membuat belum ada kejelasan dalam usaha yang mereka lakukan.

Solusi yang ditawarkan sesuai permasalahan mitra yaitu:Pendampingan perubahan perilaku harus dilakukan secara berkesinambungan untuk membangun perilaku-perilaku positif dan mengembalikan kebiasaan-kebiasaan dan nilai-nilai spiritual yang dikenalinya dulu saat belum menjadi seorang pecandu. Orang-orang terdekat adalah hal penting dalam proses pemulihan seorang pecandu. Oleh karena itu pembangunan kapasitas dan kemampuan orang-orang terdekat termasuk keluarga dan pasangan juga harus diperhatikan sehingga mereka dapat terlibat dan menjadi subyek atas proses pendampingan seorang korban napza agar mereka mendapatkan dukungan dan pendampingan yang intensif dan berkesinambungan.

Pendampingan usaha dan keterampilan yang sesuai dengan syariat Islam adalah salah satu penyiapan diri mantan korban Napza agar dapat melanjutkan keberlangsungan hidupnya sebagai seorang manusia yang memiliki 3 kebutuhan dasar sebagaimana manusia yang lainnya. Kemandirin atas dirinya sendiri dan kemandirian atas penyediaan kebutuhan dimaksud adalah sesuatu yang tidak dapat dipungkiri dalam hidup setiap manusia bahkan seorang mantap korban Napza sekalipun. Oleh karenanya maka keterampilan yang dimilikinya harus dapat dikembangkan minimal agar mereka dapat memenuhi kebutuhan dasarnya sebagai manusia dan melanjutkan keberlangsungan hidupnya. 


\section{MATERI DAN METODE}

Sesuai hasil pengamatan dan diskusi dengan kelompok mantan korban napza di yayasan Grapiks, bahwa mantan korban napza mengalami permasalahan utama yaitu mengenai perubahan perilaku serta kemampuan usaha, Hal-hal tersebut menyebabkan mitra belum siap kembali kemasyarakat. Untuk itu, metode pendekatan yang ditawarkan untuk mengatasi permasalahan tersebut; pertama upaya perubahan perilaku dari anggota kelompok mitra yaitu pendampingan perubahan perilaku dengan cara perawatan pemulihan korban napza secara berkesinambungan dengan melibatkan keluarga atau pasangan (Gunawan, N.F.N. 2016), oleh karena itu pembangunan kapasitas dan kemampuan keluarga dan pasangan juga harus diperhatikan sehingga mereka dapat terlibat dan menjadi subyek atas proses pendampingan seorang korban napza agar mereka mendapatkan dukungan dan pendampingan yang instensif dan berkesinambungan.

Metode pendekatan yang kedua yaitu pelatihan untuk peningkatan pengetahuan dan keterampilan mantan korban napza (Lupiyoadi, R. 2014) dengan memberikan pelatihan kewirausahaan yang sesuai dengan bisnis Islam. (Srisusilawati, P. 2019). Metode pendekatan ketiga yaitu pendampingan terhadap mantan korban napza mitra untuk monitoring dan evaluasi usaha / keterampilan mitra dan juga tetap mengontrol psikologi mereka akan ketergantungan Napza nya. Kegiatan pendampingan dilakukan selama kegiatan PKM dan setelah program PKM selesai sesuai dengan kesepakan yang dibuat dengan mitra.

Metode-metode kegiatan tersebut di atas akan direalisasikan dalam bentuk rencanarencana kegiatan yaitu: berdasarkan metode pendekatan tersebut maka rencana kegaiatan yang ditawarkan dalam program ini adalah melakukan kegiatan yang melibatkan mantan korban napza yang ada di yayasan grapiks dalam bentuk konsultasi, pelatihan dan pendampingan.
Materi-materi pelatihan meliputi:Pelatihan kewirausahaan yang direncanakan meliputi penggalian potensi kewirausahaan korban napza, pengembangan usaha yang sudah ada di yayasan grapiks yaitu: riil pembuatan kas, mengisi buku kas, pembuatan dan dan pengisian buku pembelian dan penjualan, penataan administrasi dengan mencatat semua aktivitas usaha selama proses pengelolaan produk dan jasa, latihan menghitung semua komponen biaya pengeluaran termasuk penyusutan alat dan nilai produk / jasa perbulan dan keuntungan perbulan (Soekartawi, 2005), (Setia Atmaja,Lukas, 2008), (Sartono Agus,2010). Perilaku pasar untuk mengetahui kapasitas pembeli atau konsumen yang akan disesuaikan dengan kapasitas produksi. Pengarahan tentang cara mencari informasi tentang calon pembeli, jenis pembeli atau tempat pemasaran produk, metode pemasaran produk. (Pilip Kotler dan Kevin Lane Keller,2008), (Hermawan Kertajaya dan Muhammad Syakir Sula, 2006). (Veithzal Rivai, 2012). Penggalian potensi usaha dan penataan manajemen usaha terus dilakukan hingga 7-8 bulan. Sedangkan pengembangan pasar akan produk/ jasa dan pendampingan tim pelaksana PKM hingga bulan terakhir masa pelaksanaan program ini dan setelah program PKM ini selesai.

Pendampingan atas kecenderungan perilaku kelompok mantan korban napza akan terus dilakukan secara berkesinambungan dalam masa pelaksanaan program dan setelah program PKM ini selesai dengan pendekatan lebih pada penenerapan sistem syariah yaitu, pengajian, diskusi religi, konsultasi dengan sistem psikologi komunikasi dalam penerapan nilai-nilai keislaman (Lis Yulianti, 2016)

Mantan korban napza sebagai mitra dalam program ini telah berpartisipasi dalam setiap tahapan kegiatan yang direncanakan. Keterlibatan mitra dimulai sejak tahapan perumusan masalah pokok yang dihadapi, menetapkan prioritas masalah yang akan ditangani, juga sebagai pelaku dalam kegiatan pelatihan dan pendampingan 
dalam kegiatan usaha juga dalam psikologi komunikasi nilai-nilai keislaman. Diharapkan setelah mengikuti kegiatan ini, mitra dapat berperan sebagai sumber informasi yang akan mentransfer ilmu dan keterampilan yang telah diperoleh kepada korban napza yang lain. Harapan dari kegiatan yang dilakukan yaitu agar timbulnya wirausaha baru yang berkelanjutan dan berkembang ke depan yang sesuai dengan Syariat Islam sehingga mantan korban napza dapat melangsungkan hidupnya di masyarakat dengan bisa memertahankan tidak menggunakan Napza lagi.

Program PKM Rehabilitasi sosial ekonomi berbasis syariah bagi mantan korban napza di Yayasan Grapiks Desa Cimekar Kecamatan Cileunyi Kabupaten Bandung Provinsi Jawa Barat rencana akan dilaksanakan oleh dosen manajemen Syariah (Popon Srisusilawati sebagai ketua PKM) dan Hukum Islam (Panji Adam) Prodi Hukum Ekonomi Syariah Fakultas Syariah dan dosen Psikologi (Ayu Tuty Utami) sebagai konsultan. Kegiatan ini melibatkan 4 orang mahasiswa yaitu dari prodi Hukum Ekonomi Syariah dan Psikologi. Ketiga dosen pengusul memiliki pengalaman pendampingan kegiatan usaha masyarakat meliputi produksi, jasa, kualitas, manajemen usaha dan pemasaran produk dan jasa. Sedangkan dari psikologi memang berpengalaman dalam psikologi komunikasi nilai-nilai Islam.

Materi pelatihan meliputi 11 makalah yang akan dibawakan oleh masing-masing anggota tim dan narasumber sedangkan mahasiswa dilibatkan dalam setiap pelatihan dan pendampingan dengan memperhatikan latar belakang pendidikan dan pengalaman tim.

Tabel 1. Latar belakang Pendidikan

\begin{tabular}{|c|c|c|c|}
\hline No. & Materi & Tim & Keahlian \\
& $\begin{array}{c}\text { Pelatihan/T } \\
\text { ugas }\end{array}$ & $\begin{array}{c}\text { Pelaksana } \\
\text { dan }\end{array}$ & $\begin{array}{c}\text { Dan } \\
\text { Pengalam }\end{array}$ \\
\hline
\end{tabular}

\begin{tabular}{|c|c|c|c|}
\hline & $\begin{array}{c}\text { Masing- } \\
\text { Masing } \\
\text { Anggota } \\
\text { Tim/Naras } \\
\text { umber }\end{array}$ & $\begin{array}{l}\text { Narasumb } \\
\text { er }\end{array}$ & an \\
\hline 1 & $\begin{array}{l}\text { Menggali } \\
\text { kemampua } \\
\mathrm{n} \\
\text { kewirausah } \\
\text { aan, } \\
\text { pelatihan } \\
\text { manajemen } \\
\text { usaha } \\
\text { sesuai } \\
\text { syariah dan } \\
\text { pendampi } \\
\text { ngan (5 } \\
\text { makalah) }\end{array}$ & $\begin{array}{l}\text { Popon } \\
\text { Srisusilaw } \\
\text { ati, S.E.I., } \\
\text { M.E.Sy. } \\
\text { (Tim } \\
\text { Pelaksana) } \\
\text { dibantu } \\
\text { mahasiswa } \\
: \\
\text { Riska } \\
\text { Ariani } \\
\text { Siregar, } \\
\text { Yovanka } \\
\text { Graciela } \\
\text { Rois, } \\
\text { Tahany, } \\
\text { Fairuz } \\
\text { Syifa } \\
\text { Rosyidah }\end{array}$ & $\begin{array}{l}\text { Manajem } \\
\text { en } \\
\text { pemasara } \\
\text { n, pelaku } \\
\text { wirausah } \\
\text { a dan } \\
\text { pegiat } \\
\text { PKM }\end{array}$ \\
\hline 2 & $\begin{array}{l}\text { Penyuluhan } \\
\text { pendekatan } \\
\text { diri kepada } \\
\text { Allah, } \\
\text { NAPZA } \\
\text { berdasarka } \\
\text { n hukum } \\
\text { Islam (4 } \\
\text { Makalah) }\end{array}$ & $\begin{array}{l}\text { Panji } \\
\text { Adam, } \\
\text { S.Sy., M.H. } \\
\text { ( Tim } \\
\text { Pelaksana) } \\
\text {. Dibantu } \\
\text { mahasiswa } \\
\text { Riska } \\
\text { Ariani } \\
\text { Siregar, } \\
\text { Yovanka } \\
\text { Graciela } \\
\text { Rois, } \\
\text { Tahany, } \\
\text { Fairuz } \\
\text { Syifa } \\
\text { Rosyidah }\end{array}$ & $\begin{array}{l}\text { Hukum } \\
\text { Islam dan } \\
\text { pegiat } \\
\text { PKM }\end{array}$ \\
\hline 3 & $\begin{array}{l}\text { Bahaya } \\
\text { Napza, } \\
\text { Pendampi } \\
\text { ngan } \\
\text { perubahan } \\
\text { perilaku } \\
\text { korban } \\
\text { napza } \\
\text { makalah) }\end{array}$ & $\begin{array}{l}\text { Ayu Tuty } \\
\text { Utami, } \\
\text { S.Psi., } \\
\text { M.Psi. } \\
\text { Tim } \\
\text { Pelaksana) } \\
\text {. Dibantu } \\
\text { mahasiswa } \\
\text { Riska } \\
\text { Ariani } \\
\text { Siregar, } \\
\text { Yovanka }\end{array}$ & $\begin{array}{l}\text { Konsultan } \\
\text { dan } \\
\text { penggiat } \\
\text { PKM }\end{array}$ \\
\hline
\end{tabular}




\begin{tabular}{|l|l|l|}
\hline & Graciela & \\
& Rois, & \\
Tahany, & \\
& Fairuz & \\
Syifa & \\
& Rosyidah & \\
\hline
\end{tabular}

\section{HASIL DAN PEMBAHASAN}

Salah satu permasalahan yang selama ini dihadapi oleh para mantan korban NAPZA adalah mengenai perilaku, yang cenderung akan kembali menggunakan Peran aktif keluarga dalam proses penyembuhan sangat dibutuhkan agar mereka tidak kembali menggunakan. Sehingga kami tim pengabdi sudah melakukan pendekatan terhadap mantan Korban NAPZA yang ada di Yayasan grapiks. Melalui mendekatan terhadap korban kami pun dapat berkomunikasi dengan keluarganya. Karena hal ini sangat penting untuk keberlangsungan hidupnya dimasa depan. Pendampingan melalui pendekatan terhadap korban dan keluarga masih berlangsung.

Gambar 2. Pandampingan melalui pendekatan terhadap korban.

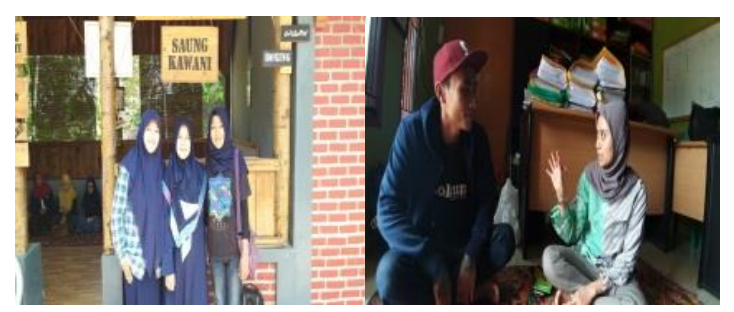

Pendekatan lain yang sudah dilakukan adalah dalam meningkatakan keberlangsungan hidupnya dalam perekonomian tim kami sudah melakukan pendekatan melalui pelatihan kewirausahaan yang sesuai dengan bisnis Islam. Dalam hal ini kami memberikan pelatihan furniture valet kepada para mantan korban NAPZA yang ada di Yayasan Grapiks. Metode yang dilakukan lebih ke diskusi santai dikarena kan dengan kondisi korban NAPZA tersebut, yang tadinya metode ceramah di ubah hanya langsung lebih ke diskusi dengan mengundang pakar, yaitu pakar resiko dan dampak buruk penggunaan NAPZA dari Indonesia Aids
Coalition (IAC), Napza dalam pendekatan hukum Islam dari dosen Fakultas Syariah Unisba, manajemen usaha berbasis Syariah dosen manajemen pemasaran Syariah dan pembekalan keterampilan yaitu praktek langsung oleh praktisi Furnitur Vallet dari Wanimallet.

Gambar 2. Praktek langsung oleh praktisi oleh praktisi Furnitur Vallet dari Wanimallet.

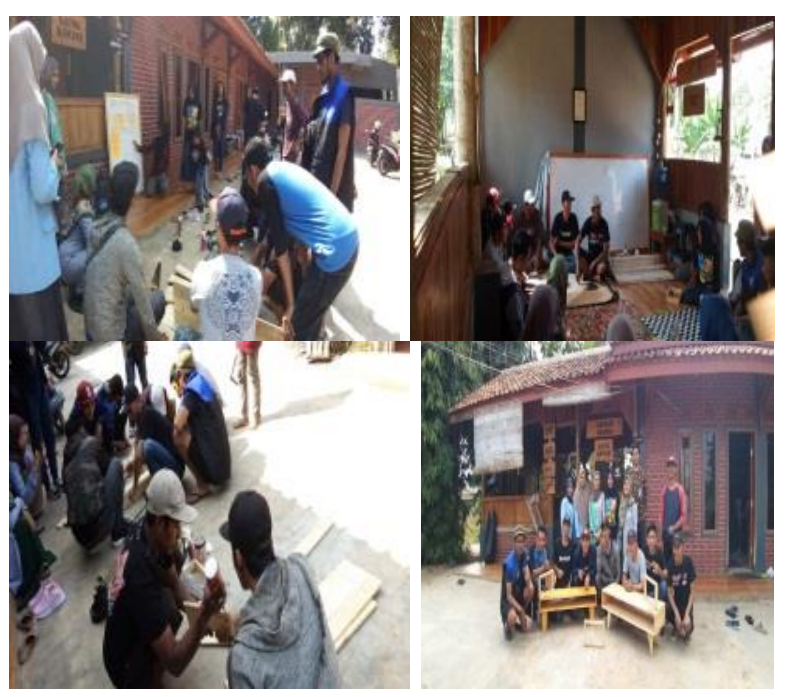

Metode demonstrasi menuntut peserta untuk memahami materi yang disampaikan dan bisa menerapkan materi yang disampaikan tersebut dengan diberikan beberapa latihan berupa soal-soal yang harus dijawab sebagai alat ukur apakah peserta latihan mampu menyerap materi latihan atau tidak.

Pada pertemuan pertama dilakukan pretest untuk mengetahui kemampuan awal. Hasil menunjukkan rata-rata nilai pre-test sebesar 30.3 Metode pengukuran untuk mengetahui pemahaman peserta menggunakan metode pre test dan post test. Berikut ini hasil dari pre test dan post test.

Tabel 2. Rangkuman hasil pengabdian

\begin{tabular}{cccc}
\hline Kelas & $\begin{array}{c}\text { Rata-rata } \\
\text { Pre Test }\end{array}$ & $\begin{array}{c}\text { Rata-rata } \\
\text { Post Test }\end{array}$ & Peningkatan \\
\hline Materi 1 & 27,32 & 73,14 & 45,82 \\
Materi 2 & 37,38 & 83,63 & 46,25 \\
Materi 3 & 26,22 & 87,39 & 61,17 \\
\hline
\end{tabular}

Hasil pengujian menunjukkan nilai rata-rata post tes sebesar 81,39. Meningkatnya hasil 
pengujian ini tidal terlapas dari metode pelatihan yang dilakukan diskusi dan praktek sehingga para peserta dapat bertanya secara langsung kepada pakar. Sedangkan mengenai perilaku sampai saat ini kami masih melakukan pendampingan.

\section{KESIMPULAN DAN IMPLIKASI}

\section{Kesimpulan}

Berdasarkan hasil perhitungan dan pembahasan dapat disimpulkan :

Tahap pelatihan Pada tahap ini, telah diadakan diskusi dan pelatihan kepada para korban NAPZA di Yayasan Grapiks. Diskusi ini difokusnya pada pengalihan korban NAPZA agar bisa menjalankan hidupnya secara normal dapat diterima oleh keluarga dan masyarakat dengan dibekali keterampilan usaha yang sesuai dengan bisnis Islam.

Tahap pendampingan Tahap ini, tim melakukan pendampingan kepada para korban NAPZA dan keluarganya terutama masalah perilaku. Pendampingan usaha yang sesuai Syariah yaitu mengenai usaha furniture valet, hal ini sudah meningkatkan keterampilan korban NAPZA mengenai pembuatan furniture tersebut.

Evaluasi Tahapan ini merupakan proses pengukuran keberhasilan ketercapaian luaran dan target yang ditetapkan. Pengukuran tersebut dilakukan dengan menggunakan indikator-indikator tertentu. Evaluasi dilakukan setiap setelah dilakukan kegiatan dan dilakukan penyebaran kuesioner baik di awal maupun di akhir untuk mengetahui tingkat kepuasan dan keberhasilan program PKM ini kepada para peserta.

Metode pre test dan post Hasil pelatihan rata-rata yang dilakukan dengan metode pre test dan post test yaitu nilai rata-rata pada pre test sebesar pre test menjadi 81.39 pada post test dengan demikian mengalami peningkatan.

\section{Implikasi}

Adapun hasil pengabdian di Yayasan Grapiks, memberikan implikasi antara lain: Perlunya dukungan dari setiap pihak seperti masyarakat sekitar serta instansi. Perlunya Pendampingan secara khusus terhadap keluarga agar mereka dapat menerima anggota keluarganya, pendampingan kepada korban Napza secara intensif, dilakukan PKM lanjutan dengan melakukan dampingan dan pelatihan lebih khusus dalam pengelolaan usaha yang berbasis Syariah dan dilakukan PKM lanjutan untuk pembentukan kelompok untuk pengelolaan usaha furnitur valet bagi korban Napza agar bisa memanfaatkan keterampiran yang sudah diperoleh dalam PKM ini sehingga mereka bisa melangsungkan kehidupannya terutama dalam hal perekonomian.

\section{UCAPAN TERIMAKASIH}

Segala puji dan syukur senantiasa penulis panjatkan kepada Allah Azza Wajallah, atas segala nikmat, rahmat dan karunia-Nya sehingga jurnal pengabdian.

\section{DAFTAR PUSTAKA}

Gunawan, N. F. N. (2016). Rehabilitasi Sosial Berbasis Masyarakat Bagi Korban Penyalahgunaan Napza. Sosio Konsepsia, 18-38.

Hermawan Kertajaya dan Muhammad Syakir Sula, (2006), Syariah Marketing, Bandung, Mizan Pustaka.

Jabar.Tribunnews.com Sabtu, 28 Juli 2018

Lis Yulianti Syafrida Siregar (2015) Peran Psikologi komunikasi dalam Penerapan Nilai-nilai Keislaman di keluarga. Jurnal IAIN padangsidimpuan.ac.id

Lupiyoadi, R. (2014). Pemasaran Jasa.1-40

Pilip Kotler dan Kelvin Lane Keller,(2008), Manajemen pemasaran,edisi ke tiga belas, Jakarta, Madani Erlangga.

Santos, S, (2006), Aplikasi Excel dalam Statistik Bisnis. Elex Media Komputindo, Jakarta. 
Sartono Agus, (2010), Manajemen Keuangan Teori dan Aplikasi, Yogyakarta, Cetakan ke empat, BPFE IKAPI.

Setia Atmaja, Lukas, (2008), Teori dan Praktik Manajemen Keuangan, Yogyakarta, Andi.

Soekartawi, (2005), Agribisnis, Rajagrafindo Pesada, Jakarta.
Srisusilawati, P. (2019). Efektivitas Ekonomi Produktif Bagi Mantan Korban Napza (Studi Kasus di Yayasan Grapiks Bandung).Jurnal Sosial Ekonomi Dan Humaniora, 5(1), 8-16.

Veithzal Rivai, (2012), Islamic Marketing, Jakarta, PT Gramedia Pustaka Utama. 